doi: $10.18575 / \mathrm{msrs}$. sm.e. 18.10 UDC: $616.13-007.64 / .141$ COBISS.RS-ID: $731855^{2}$

\title{
Right Pulmonary Artery Aneurysm Mimicking Tumor on Chest X-Ray in Patient with Eisenmenger Syndrome
}

\begin{abstract}
A 66-year-old patient with previously diagnosed largeventricular septal defect and Eisenmenger syndrome (ES) performed a preoperative(planned inguinal hernioplasty)chest $\mathrm{x}$-ray that showed a tumor-like lung mass, which led to a chestCT scan. The ChestCT scan showed an extremely dilated right pulmonary artery which mimicked tumor with rarely described atherosclerotic changes in the right blood flow with calcified plaques and thrombotic masses. Since pulmonary artery thrombosis is common in adults with ES, it is our belief that anticoagulation should be considered in this group of patients.
\end{abstract}

Key words: Eisenmenger syndrome, ventricular septal defect, pulmonary artery aneurysm

(Scr Med 2018:49:61-64)

\author{
Amra Macić-Džanković ${ }^{1}$, \\ Lamija Pojskić ${ }^{2}$ \\ Belma Pojskić, \\ Fuad Džankovićc \\ Gordan Bajićc 4
}

${ }^{1}$ General Hospital "Prim. Dr Abdulah Nakaš",Sarajevo

${ }^{2}$ Cantonal Hospital Zenica

${ }^{3}$ Clinic for Orthopedic and Trauma, University-Clinical Center Sarajevo

${ }^{4}$ Pan-European University

"APEIRON”, Banja Luka

\section{Contact address:} AmraMacić - Džanković, Department of Cardiology,General hospital „Prim. Dr Abdulah Nakaš“ 12 Kranjčevićeva, 71 ooo Sarajevo Bosnia i Herzegovina e-mail:amradzan@gmail.com phone number: +387-61-177-743 $+387-33-285-412$

Submitted: February $8^{\text {th }}, 2018$ Accepted February 28 ${ }^{\text {th }}, 2018$

\section{Introduction}

Eisenmenger syndrome (ES) is defined as pulmonary vascular obstructive disease that develops as a consequence of large preexisting left-to-right shunt. In ES, pulmonary artery pressures approach systemic levels and the direction of the flow becomes bidirectional or right-to-left. Lesions in Eisenmenger's syndrome, such as large septal defect, are characterized by high pulmonary pressure, high pulmonary vascular resistance and/or a high pulmonary flow state, and they are associated with pulmonary vascular disease. ES is rarely described in the elderly because congenital heart defects such as ventricular septal defect(VSD) are usually treated in childhood. ${ }^{1}$ Recent studies have demonstrated some hypotheses about possible etiologies of pulmonary artery thrombosis in ES. In these studies are listed pathophysiological mechanisms that are considered most likely to lead to thrombosis: local vascular injury from progressive pulmonary hypertension,hypercoagulability and sluggish flow in the pulmonary artery, which promote red cellaggregation.Some of them suggest that the pulmonary artery atherosclerosis is responsible for thrombosis. ${ }^{2}$

\section{Case Study}

A 66 year-old man with previous cardiac disease (VSD andES) was referred to our hospital for detailed diagnostic evaluation of huge right hilar lung mass found on routine chest X-ray during preoperative evaluation foringuinal hernioplasty.(Fig.1.)

Patient had a 1-year history of dyspnea.Physical findings include dyspnea, central cyanosis and systolic mild murmur in left parasternal intercostal space. Laboratory 
findings showed secondary polycythemia (Red blood cell level - 8.66 x109/L,Hemoglobin level - 222 g/L, Hematocrit level - 0.70, Erythrocyte sedimentation rate $-2 \mathrm{~mm}$,Potassium $3.32 \mathrm{mmol} / \mathrm{L}$, Ferrum level $10.10 \mu \mathrm{mol} / \mathrm{L}$, cholesterol $7.30 \mathrm{mmol} / \mathrm{L}$ ).Arterial blood gases analysis showed extreme hypoxia $(\mathrm{pH} 7.383, \mathrm{pCO} 2$ 5.62, pO2 5.52, $\mathrm{sO} 2$ 75.8).

\section{Figure 1. Chest CT Scan}

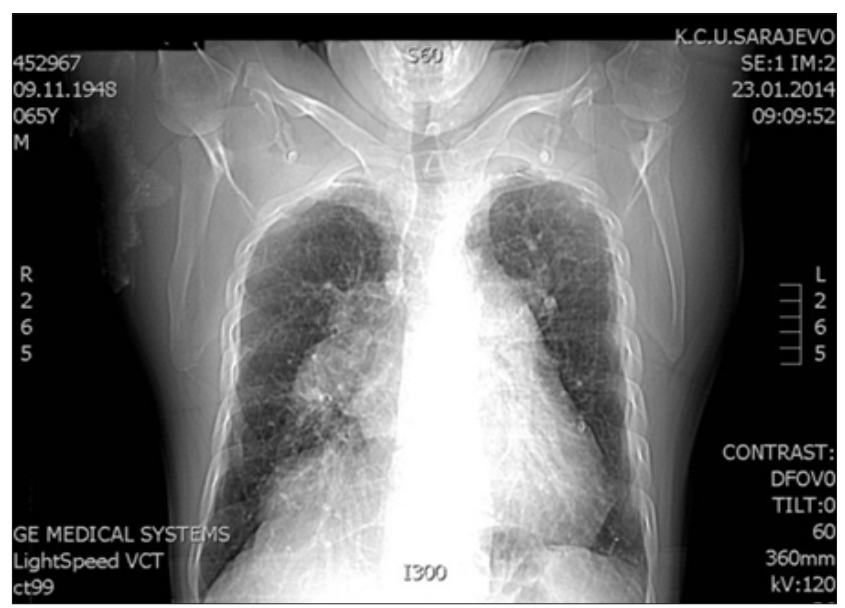

ECG showed signs of right axis with incomplete right bundle branch block and posterior left hemiblock, inverted $\mathrm{T}$ wave in lead II and III, aVF, and right precordial leads - V2, V3 withST segment depression in leads V4-V6.(Fig.2.)

Figure 2. Transtorocal Echocardiography showing VSD

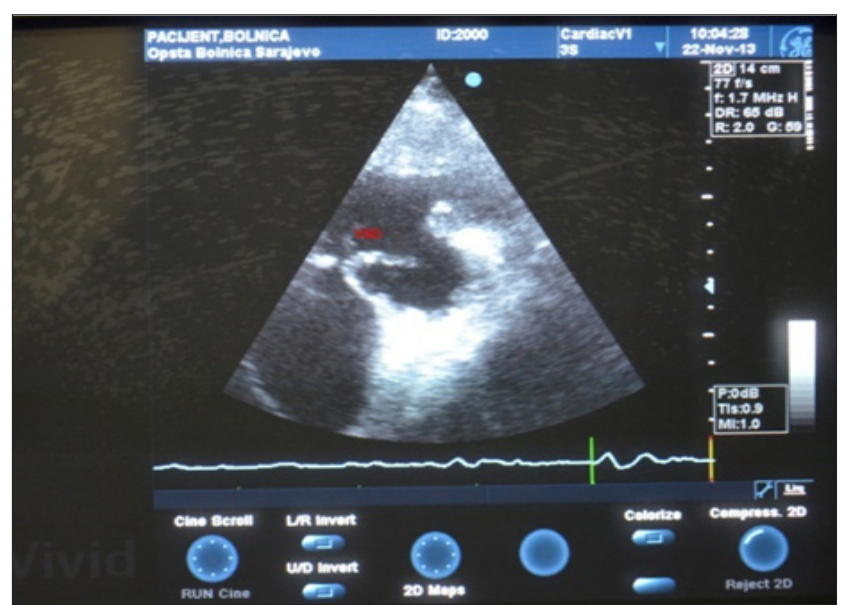

Echocardiogram verified extreme hypertrophy of both right and left ventricular walls, paradox moving of interventricular septum with calculated RYSP over 120 $\mathrm{mm} \mathrm{Hg}$, large muscularseptal defect $(23 \mathrm{~mm})$ associated with bidirectional dominantly right-to-left shunt and severe pulmonary hypertension with PAPS over 120 mm Hg. Transesophageal echocardiography was not performed due to poor transesophageal window and insufficient view of cardiac structures.(Fig.3.)

Figure 3. Chest CT scan showing right tumor-like lung mass

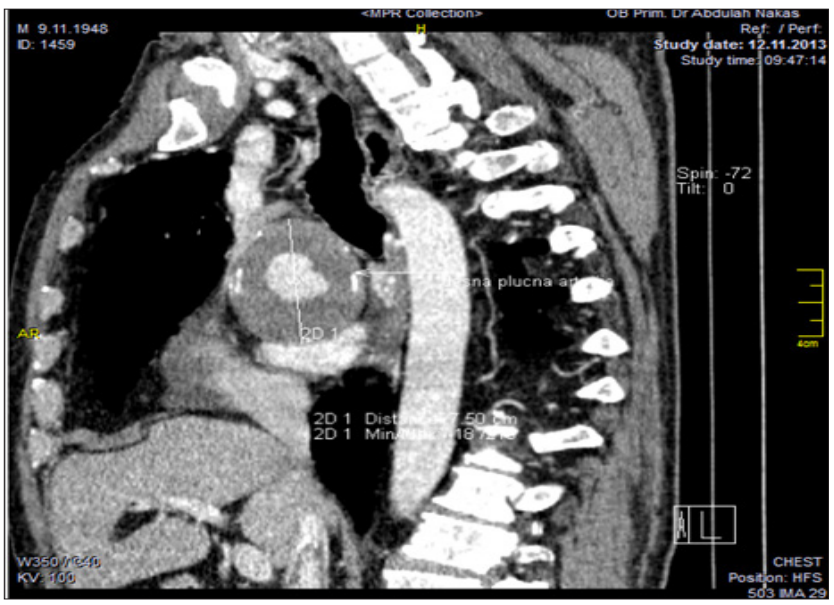

Contrast-Enhanced Computed Tomography (CT) of heart confirmed the existence of ventricular septal defect and also showed extremely dilated right pulmonary artery $(56 \mathrm{~mm}$ in diameter) with large intraluminal thrombus, which incompletely obturated lumen,and laminar calcifications $(75 \mathrm{~mm})$. Lobar branches of right pulmonary artery for superior and middle lobe were completely obturated with the thrombotic mass. CT scan also showed strong bronchial collateral circulation.

\section{Discussion}

We described the case of older patient with ES secondary to large VSD and giant thrombosed right pulmonary artery aneurism(PAA) which initially presented on chest X-ray as large paracardial right tumorous lesion. Further investigation (chest CT with contrast) showed, apart from previously diagnosed VSD, atherosclerotic changes in pulmonary circulation with extremely dilated right pulmonary artery in which large thrombotic mass obturated lumen of lobar branches for the upper and middle lobe of the right lung. These findings (atherosclerotic changes in pulmonary circulation with secondary thrombosis) have showed us that, in this case, pulmonary vessels mimic systemic circulation, which makes it very interesting. Pulmonary artery aneurysm is an infrequent disease of the pulmonary vasculature; and in more than $50 \%$ of cases is caused by congenital heart disease. ${ }^{3}$ Patient history and clinical clues are essential for the recognition of PAA, since it is rare and unlikely cause of suspected lung mass. ${ }^{4}$ In our patient,VSD with left-to-right shunt increased the volume and pressure 
load on the pulmonary artery circulation; then secondary pulmonary hypertension increased hemodynamic shear stress on the vessel walls and promoted aneurysm formation in the right pulmonary artery. PAA is associated with severe complications such as pulmonary artery dissection and rupture, bronchial pressure and thrombus formation as seen in our case. About 20-30\% of the patients with ES present with pulmonary artery thrombus. ${ }^{5}$ Predictors of pulmonary thrombus formation in patients with ES are not known. In the study of Silverside et al. pulmonary artery calcifications were seen more frequently in patients with pulmonary thrombosis. Patients with ES have bleeding and clotting tendencies, as well as the labile INR, therefore it is difficult to make recommendations regarding anticoagulation in these patient. ${ }^{6}$ Since pulmonary arterial thrombosis among adults with ES is common and relates to older age, biventricular dysfunction, and slow pulmonary artery blood flow, it is our belief that oral anticoagulation should be administrated to this group of patients. ${ }^{2}$

\section{Conclusion}

In cases when the chest CT scan shows tumor-like hilar mass, extremely dilated right pulmonary artery mimicking tumor, it is necessary to perform a complete cardiology procedure.

\section{References}

1. Kaemmerer H, Mebus S, Schulze-Neick I, et al. The adult patient with Eisenmenger Syndrome: a medical Update after Dana Point Part I: epidemiology, clinical aspects and diagnostic options. Curr Cardiol Rev. 2010;6(4):343-55. https://doi.org/10.2174/157340310793566154

PMid:22043211 PMCid:PMC3083816

2. $\quad$ Broberg C.S., Ujita M., Prasad S., Li W., Rubens M., Bax B.E., et al.Pulmonary arterial thrombosis in Eisenmenger syndrome is associated with biventricular dysfunction and decreased pulmonary flow velocity. J. Am. Coll. Cardiol., 50 (7) (Aug 14 2007), pp. 634-642

https://doi.org/10.1016/j.jacc.2007.04.056

PMid:17692749

3. Theodoropoulos P, Ziganshin BA, Tranquilli M, Elefteriades JA. Pulmonary artery aneurysms: four case reports and literature review. Int J Angiol. 2013;22(3):143-48.

https://doi.org/10.1055/s-0033-1347907

PMid:24436601

PMCid:PMC3770974

4. ChungCW, Doherty JU, Kotler R, Finkelstein A, Dresdale A. Pulmonary artery aneurysm presenting as a lung mass. Chest1995;108:1164-1166. Crossref, Medline https://doi.org/10.1378/chest.108.4.1164 PMid:7555134

5. Ucar, O., Sahin, D., Vural, M. et al, Thrombosed giant proximal pulmonary artery aneurysm [in Turkish]. Turk Kardiyol Dern Ars. 2009;37:493-496. PMid:20098046

6. Silversides, C.K., Granton, J.T., Konen, E. et al. Pulmonary thrombosis in adults with Eisenmenger syndrome. J Am Coll Cardiol. 2003; 42: 1982-1987 https://doi.org/10.1016/j.jacc.2003.07.022 PMid:14662263 


\section{Aneurizma desne plućne arterije koja imitira tumor na radiografiji grudnog koša kod pacijenta sa Eisenmengerovim sindromom}

\section{SAŽETAK}

Pacijent, 66godina, sa ranije dijagnostikovanim velikim ventrikularnim septalnim defektom i Eismengerovim sindromom (ES) je obavio preoperativno obradu radi planirane operacije ingvinalne hernije. RTG grudnog koša koji je pokazao tumorozno izmijenjen desni hilus što je indiciralo CT grudnog koša.CT grudnog koša je pokazao ekstremno dilatiranu desnu plućnu arteriju koja imitira tumor uz rijetko opisane aterosklerotske promjene desnog krvotoka sa kalcificiranim plakovima i trombotskim masama. S obziromna to da je tromboza plućne arterije uobičajena kod odraslih sa ES, smatramo da je kod ove grupe pacijenata potrebno razmotriti i antikoagulantnu terapiju.

Ključne riječi: Eisenmenger-ov sindrom, ventrikularni septalni defekt, aneurizma plućne arterije 